\title{
Pengaruh Pola Pikir (Mindset) Kewirausahaan Terhadap Motivasi Dan Keterampilan Wirausaha Mahasiswa Program Studi Manajemen Universitas Muhammadiyah Sorong
}

\author{
Helmi Suaidy ${ }^{1}$, Ramli.Lewenussa ${ }^{2}$ \\ ${ }^{1}$ Fakultas Ekonomi Universitas Muhammadiyah Sorong \\ ${ }^{2}$ Fakultas Ekonomi Universitas Muhammadiyah Sorong \\ Email : irianfish@gmail.com
}

direvisi: 16 Januari 2019 dipublikasikan: 31 Januari 2019

\begin{abstract}
Abstrak
Penelitian ini bertujuan untuk mengetahui (1) besarnya pengaruh pola pikir (Mindset) kewirausahaan terhadap motivasi berwirausaha mahasiswa program studi Manajemen (2) besarnya pengaruh pola pikir (Mindset) kewirausahaan terhadap keterampilan berwirausaha mahasiswa program studi Manajemen (3) besarnya pengaruh pola pikir (Mindset) kewirausahaan terhadap motivasi dan keterampilan berwirausaha mahasiswa program studi Manajemen. Penelitian ini merupakan penelitian deskriptif dan korelasi dengan pendekatan kuantitatif. Variabel penelitian ini adalah Pola Pikir (Mindet) kewirausahaan sebagai variabel dependent (Terikat), motivasi dan keterampilan berwirausaha sebagai variabel independent (Bebas). Penelitian ini merupakan penelitian populasi dengan responden mahasiswa program studi Manajemen Universitas Muhammadiyah Sorong angkatan 2014 yang berjumlah 116 mahasiswa. Teknik pengambilan sampel menggunakan metode purposive sampling,,Teknik pengambilan data menggunakan kuesioner dan dokumentasi. Metode analisis data yang digunakan adalah regresi linier berganda dan sederhana. Hasil penelitian ini menunjukkan bahwa (1) Pola Pikir (Mindset) kewirausahaan berpengaruh positif dan signifikan terhadap motivasi berwirausaha ditunjukkan oleh nilai $F_{\text {hitung }} 38,963$ dengan nilai signifikansi 0,000 dan $R^{2}$ 0,248 (2) Pola Pikir (Mindset) kewirausahaan berpengaruh positif dan signifikan terhadap keterampilan berwirausaha dengan ditunjukkan oleh nilai $F_{\text {Hitung }} 21,708$ dengan nilai signifikansi 0,000 dan $R^{2}$ 0,160.(3) Pola Pikir (Mindset) kewirausahaan berpengaruh positif dan signifikan terhadap keterampilan berwirausaha dengan ditunjukkan oleh nilai $F_{\text {Hitung }} 22,019$ dengan nilai signifikansi 0,000 dan $R^{2}$ 0,268 .

Kata kunci : Pola Pikir (Mindset) Kewirausahaan, Motivasi Wirausaha, Keterampilan Wirausaha.
\end{abstract}




\title{
Sentralisasi Volume 8 ( 1 ) : Hal 1-17| 2019 \\ Pola Pikir (Mindset) Kewirausahan... \\ DOI: https://doi.org/10.33506/sl.v8i1.385
}

Helmi Suaidy

\begin{abstract}
This study aims to determine (1) the magnitude of the influence of entrepreneurial mindset on the motivation of entrepreneurship in Management study students (2) the magnitude of the influence of entrepreneurial mindset on entrepreneurship skills in Management study program students (3) the magnitude of the influence of mindset (Mindset) entrepreneurship towards the motivation and entrepreneurial skills of Management study program students. This research is a descriptive research and correlation with a quantitative approach. The variable of this study is entrepreneurial Mindset as a dependent variable, motivation and entrepreneurship skills as independent variables. This research is a population research with respondents of the 2014 study program at the Muhammadiyah University of Sorong University, amounting to 116 students. The sampling technique uses purposive sampling method, the data collection technique uses questionnaires and documentation. The data analysis method used is multiple linear regression and is simple. The results of this study indicate that (1) entrepreneurial mindset has a positive and significant effect on entrepreneurial motivation shown by the value of Fcount 38.963 with a significance value of 0.000 and $R 20.248$ (2) Entrepreneurship Mindset (Mindset) has a positive and significant effect on entrepreneurial skills with indicated by the value of FH 21.708 with a significance value of 0.000 and R2 0.160. (3) Entrepreneurship Mindset (Mindset) has a positive and significant effect on entrepreneurial skills as indicated by the value of $F$ count 22.019 with a significance value of 0.000 and $R 20.268$.
\end{abstract}

Keywords: Entrepreneurship Mindset (Mindset), Entrepreneurial Motivation, Entrepreneurial Skills.

\section{Pendahuluan}

Kuliah sambil berwirausaha memang belum akrab di kalangan mahasiswa. Salah satu sebabnya adalah adanya mindset di kalangan mahasiswa yang beranggapan bahwa pendidikan (kuliah) dan kerja (dalam hal ini berwirausaha) itu adalah dua hal yang berbeda, kuliah adalah untuk saat ini, dan hal itu tidak dapat dicampuri dengan hal yang berbeda seperti berwirausaha. Padahal pendapat seperti itu sangatlah merugikan, melihat sekarang ini begitu banyak potensi yang dapat dijadikan sebagai bisnis. Sabda Rasulullah SAW; 9 dari 10 pintu rizki ummatku ada di perdagangan.

Memasuki persaingan global saat ini, masalah pengangguran dan kemiskinan merupakan masalah klasik yang dialami negara-negara berkembang termasuk Indonesia.Setiap periode kepemimpinan nasional di Indonesia selalu dihadapkan pada kedua isu tersebut. Setiap tahun beratus-ratus atau berjuta-juta orang ingin bekerja atau 


\section{Sentralisasi Volume 8 ( 1 ) : Hal 1-17 | 2019 \\ Pola Pikir (Mindset) Kewirausahan... \\ DOI: https://doi.org/10.33506/sl.v8i1.385}

Helmi Suaidy

mendapatkan pekerjaan. Mereka mencoba menjadi karyawan di sebuah instansi yang dirasa sesuai dengan kemampuan yang dimiliki. Hanya sedikit yang berpikir untuk menciptakan lapangan pekerjaan. Mereka berharap menjadi karyawan, pegawai, buruh atau menjual tenaganya begitu saja sekadar mengharapkan imbalan jasa.

Data BPS menunjukan pengangguran bertambah 300 ribu orang dibanding periode yang sama tahun sebelumnya. Sehingga total pengangguran mencapai 7,45 juta orang Fenomena di atas seharusnya dapat dijadikan bahan pemikiran, bagaimana agar dapat menciptakan lapangan kerja baru yang dapat menampung karyawan, tidak lagi berpikir untuk mempersiapkan diri menjadi calon karyawan yang mencari pekerjaan, terutama bagi individu yang terdidik, misalnya Mahasiswa. Mereka diharapkan mampu menjadi penggerak perekonomian dengan menanamkan jiwa kewirausahaan semenjak dini. Masalahnya apakah wirausaha itu kemudian dijadikan tujuan ataupun hanya sekedar sambilan, itu tergantung pada kepentingan masing-masing orang. Menurut Zimmerr (1996:51) Untuk mengembangkan karakteristik dibutuhkan motivasi berwirausaha.

Motivasi Menurut teori Maslow terdapat lima kategori kebutuhan manusia, yaitu physiological needs, safety (security), social (affiliation), esteem (recognition), dan self actualization. Bila satu tingkat kebutuhan sudah terpenuhi, maka akan muncul tingkat kebutuhan yang lebih tinggi. Namun ini tidak berarti tingkat kebutuhan yang lebih rendah harus terpenuhi semuanya secara memuaskan. Bisa saja kebutuhan lebih rendah belum dapat memuaskan sama sekali, tetapi sudah muncul tingkatan kebutuhan yang lebih tinggi. Dengan motivasi akan terbentuk keterampilan berwirausaha. Menurut Husrich (dalam Basrowi, 2011 : 69) ada 3 jenis keterampilan yang dibutuhkan oleh seorang wirausaha, yaitu sebagai berikut: (1) Keterampilan teknis,(ii) Keterampilan Bisnis; (iii) Keterampilan berwirausahaan secara personal

Selama ini, dimasyarakat telah berkembang mitos umum tentang wirausaha (entrepreneur). Beberapa mitos yang berkembang diantaranya : (i) Entrepreneur adalah dilahirkan, tidak dibuat; (ii) Entrepreneur adalah pengambil resiko (risk takers); (iii) butuh uang banyak untuk menjadi sukses;(iv) yang anda butuhkan adalah gagasan besar; (v) Entrepreneur adalah serigala terasing ( lone wolves ); (vi) Entrepreneur bekerja 
sepanjang jalan yang keras. Mambangun mindset kewirausahaan harus dimulai dari adanya kesadaran diri bahwa mindset kewirausahaan dapat ditumbuhkan melalui cara dan strategi. Wirausaha bukan semata-mata masalah bakat (meskipun bakat tetap merupakan factor yang yang menjadi peluang pada suatu waktu, belum tentu menjadi peluang dilain waktu.Sekali kesempatan itu hilang,belum tentu akan kembali lagi.

Tujuan Penelitian ini 1). Mendapatkan gambaran pengaruh parsial sikap, motivasi berwirausaha Terhadap Pola Pikir (Mindset) Kewirausahaan Mahasiswa 2). Mendapatkan gambaran pengaruh parsial sikap, Keterampilan berwirausaha Terhadap Pola Pikir (Mindset) Kewirausahaan Mahasiswa 3). Mendapatkan gambaran pengaruh simultan sikap, motivasi dan keterampilan berwirausaha Terhadap Pola Pikir (Mindset) Kewirausahaan Mahasiswa .

Dalam memulai usaha dibutuhkan dua faktor penting, yang pertama skill dan yang kedua adalah mindset entrepreneur. Dari faktor itulah, mengapa adanya mindset entrepreneur sangatlah penting dalam menjalankan bisnis. Sebab dengan mindset entrepreneur, seseorang akan termotivasi untuk selalu produktif dan melakukan inovasiinovasi baru untuk menciptakan peluang usaha yang menguntungkan. Mindset is A fixed mental attitude or disposition that predetermines a person's responses to and interpretations of situations. Membuat seseorang menjadi berani mengembangkan usaha dan idenya melalui motivasi berwirausaha yang kuat. Dua hal tersebut harus saling berhubungan agar tercipta wirausaha yang kuat dan tangguh serta berkualitas.

Keterampilan adalah kemampuan untuk menggunakan akal, fikiran, ide dan kreatifitas dalam mengerjakan, mengubah dan membuat sesuatu menjadi lebih bermakna sehingga menghasilkan sebuah nilai dari hasil pekerjaan tersebut. Keterampilan akan lebih baik apabila selalu dilatih untuk menaikkan dan menambah kemampuan sehingga menjadi ahli dan menguasai. Sedangkan wirausaha adalah seseorang yang mengaktualisasi potensi diri dalam berfikir kreatif dan inovatif untuk menciptakan produk baru dan bernilai tambah guna kepentingan bersama. 


\section{Sentralisasi Volume 8 ( 1 ) : Hal 1-17 | 2019 \\ Pola Pikir (Mindset) Kewirausahan... \\ DOI: https://doi.org/10.33506/sl.v8i1.385}

Helmi Suaidy

\section{Metode Penelitian}

Penelitian ini dilakukan pada Fakultas ekonomi program studi manajemen Universitas muhammadiyah Sorong. Alasan pemilihan lokasi tersebut dikarenakan masalah yang diajukan berhubungan dengan pola pikir kewirausahaan. Sasaran penelitian ini untuk mendapatkan gambaran Pola Pikir (Mindset) Kewirausahaan minat mahasiswa menjalankan wirausaha. Caranya adalah dengan melihat beberapa variabel antara motivasi dan keterampilan yang menumbuhkan pola pikir (mindset) kewirausahaan. Sampel dalam penelitian ini adalah individu dari mahasiswa atau kelompok mahasiswa pada semester IV dan VI sebanyak 30 orang dari populasi mahasiswa baru diambil secara acak.

Metode penelitian ini adalah deskriptif korelasi dengan pendekatan analisis kuantitatif. Tujuannya adalah untuk menguji faktor-faktor yang mempengaruhi, Motivasi dan Keterampilan berwirausaha mahasiswa. Metode pengumpulan data menggunakan instrumen kuesioner dengan responden sebanyak 30 orang. Metode yang digunakan adalah Purposive Sampling dengan tingkat kesalahan 5\%. Data diolah dan dianalisis dengan menggunakan bantuan software SPSS for Windows seri 20.0

Tabel 3 Definisi Operasional

\begin{tabular}{cl}
\hline Variabel & \multicolumn{1}{c}{ Definisi Operasional } \\
\hline $\begin{array}{c}\text { Pola Pikir (Mindset) } \\
\text { Kewirausahaan } \\
(\mathbf{Y})\end{array}$ & $\begin{array}{l}\text { Definisi Mindset Enterpreneur adalah kerangka berpikir } \\
\text { seseorang yang beorientasikan entrepreneurial, lebih memilih } \\
\text { untuk menjalani ketidakpastian daripada menghindarinya, } \\
\text { melihat segala sesuatu lebih sederhana daripada orang lain, dan } \\
\text { mau belajar yang berresiko }\end{array}$ \\
\hline $\begin{array}{c}\text { Motivasi } \\
\text { Berwirausaha }\left(\mathbf{X}_{1}\right)\end{array}$ & $\begin{array}{l}\text { Motivasi merupakan salah satu faktor keberhasilan wirausaha } \\
\text { dalam menyelesaikan tugasnya. Semakin besar motivasi maka } \\
\text { semak in besar kesuksesan yang dicapai. }\end{array}$ \\
\hline Keterampilan & $\begin{array}{l}\text { Keterampilan yang harus dimiliki wirausaha diantaranya, } \\
\text { adalah: Keterampilan konseptual. Keterampilan kreatif, } \\
\text { Kerwirausaha }\left(\mathbf{X}_{2}\right)\end{array}$ \\
& Keterampilan berkom unikasi dan berinteraksi,
\end{tabular}

Sampel yang diambil dari populasi yang ada dilakukan secara Purposive Sampling, dengan menggunakan tingkat kesalahan 5\%, dari daftar pengambilan sampel yang 
dianggap representatif (Sugiyono, 2003). Prinsip pemilihan sampel dalam desain ini adalah setiap elemen dalam populasi mempunyai kesempatan yang sama untuk dipilih (Kuncoro, 2003).

\section{Prosedur Pengumpulan Data}

Cara pengumpulan data dalam suatu penelitian ada dua jenis sumber data, yaitu data primer (responden) dan data sekunder (penunjang). Kedua data tersebut sangat penting atau diperlukan untuk ketepatan sejumlah informasi yang relevan dengan data tentang variabel-variabel penelitian. Kedua data tersebut juga penting untuk menyederhanakan data yang akan dikumpulkan, sehingga penelitian ini dapat membuat kesimpulankesimpulan data yang dikumpulkan.

Pengumpulan data dalam penelitian ini dilakukan dengan melakukan survei lapangan menggunakan kuesioner. Data dikumpulkan dengan cara melakukan penyebaran kuesioner secara langsung ke responden yang menjadi sampel penelitian. Hal ini dilakukan bertujuan untuk memperoleh data berupa jawaban-jawaban dari para responden.

\section{Tahap Uji Validitas dan Reliabilitas}

Instrumen dikatakan valid apabila instrumen tersebut dapat dengan tepat mengukur apa yang hendak diukur. Uji validitas dan reliabilitas dilakukan dengan menggunakan software SPSS for Windows seri 20.0. Uji validitas digunakan untuk mengukur kevalidan suatu kuesioner. Suatu kuesioner dikatakan valid apabila pertanyaan atau pernyataan pada kuesioner mampu mengungkapkan sesuatu yang akan diukur oleh kuesioner tersebut.

\section{Analisis Data}

Data yang telah terkumpul kemudian dilakukan pengolahan data dengan menggunakan cara sebagai berikut: 1) Pemeriksaan data (editing), sebelum dilakukan pengolahan data, perlu data tersebut diperiksa lebih dahulu. Jadi, dalam penelitian ini disediakan instrumen angket yang berisi 30 pertanyaan mengenai pengetahuan wirausaha; 2) Pembuatan kode (coding), melakukan coding terhadap data yang sudah diedit, sebagai usaha untuk menyederhanakan data, yaitu dengan memberi tanda di angka 1-5 pada 
masingmasing kategori jawaban dari seluruh responden. Adapun nilai sangat setuju diberi kode dengan skor 5, nilai setuju diberi skor 4, Netral diberi skor 3, nilai tidak setuju diberi skor 2, dan nilai sangat tidak setuju diberi skor 1 .

Data diolah dan dianalisis dengan menggunakan bantuan software SPSS for Windows seri 20.0. Analisa data merupakan bagian yang amat penting dalam metode ilmiah karena dengan analisa data tersebut dapat diberi arti dan makna yang berguna dalam memecahkan masalah. Oleh karena itu, tujuan penelitian ini agar dicapai secara optimal, maka data dianalisis secara analisis regresi linier sederhana dan berganda.

Analisis Regresi Linear Sederhana memiliki tujuan untuk melakukan pengujian seberapa besar hubungan antara variabel dependen dengan variabel independen Analisis regresi linear sederhana digunakan untuk menguji variabel independen secara individual terhadap variabel dependen. Analisis ini digunakan untuk menguji hipotesis 1, dan 2 yaitu Motivasi Berwirausaha $\left(\mathrm{X}_{1}\right)$ terhadap Pola Pikir ( Mindset) Kewirausahaan (Y), Keterampilan Berwirausaha $\left(\mathrm{X}_{2}\right)$ terhadap terhadap Pola Pikir ( Mindset) Kewirausahaan (Y). Langkah dalam menganalisis menggunakan regresi linear sederhana sebagai berikut:

Persamaan regresi linear sederhana

Keterangan:

$$
\mathrm{Y}=\mathrm{a}+\mathrm{bX}
$$

$$
\begin{aligned}
& Y: \text { Nilai yang diprediksikan } \\
& \text { a }: \text { Konstanta atau bila harga } X=0 \\
& \mathrm{~b}: \text { Koefisien regresi } \\
& \mathrm{X}: \text { Nilai variabel independen }
\end{aligned}
$$

Analisis regresi linear berganda digunakan untuk mencari besarnya hubungan secara linear antara dua atau lebih variabel independen Motivasi Berwirausaha $\left(\mathrm{X}_{1}\right)$, Keterampilan Berwirausaha $\left(\mathrm{X}_{2}\right)$, secara bersamaan dengan variabel dependen berupa Pola Pikir ( Mindset ) Kewirausahaan (Y). Membuat Persamaan garis dua prediktor

$$
\mathrm{Y}=\mathrm{a}+\mathrm{b}_{1} \mathrm{X}_{1}+\mathrm{b}_{2} \mathrm{X}_{2}
$$


Keterangan:

$\begin{array}{ll}\mathrm{Y} & : \text { Minat berwirausaha } \\ \mathrm{a} & : \text { Konstanta (nilai Y' apabila } X 1, X 2 \ldots \ldots X n=0) \\ \mathrm{b} & : \text { Koefisien linear berganda } \\ X 1 & : \text { Pengetahuan kewirausahaan } \\ X 2 & \text { : Motivasi berwirausaha }\end{array}$

Menguji regresi linear berganda melalui uji $\mathrm{F}$

$$
\mathrm{F}_{\mathrm{h}}=\frac{\mathrm{R}^{2} / \mathrm{k}}{\left(1-\mathrm{R}^{2}\right) /(\mathrm{n}-\mathrm{k}-1)}
$$

Keterangan:

$$
\begin{aligned}
& F h: \text { Harga F garis regresi } \\
& R \quad: \text { Koefisien korelasi ganda } \\
& \mathrm{k} \text { : Jumlah variabel independen } \\
& \mathrm{n} \quad: \text { Jumlah anggota sampel }
\end{aligned}
$$

Koefisien determinasi $\left(R^{2}\right)$ antara prediktor $\mathrm{X}_{1}, \mathrm{X}_{2}$ dengan $\mathrm{Y}$

Keterangan:

$$
\mathrm{R}^{2} \mathrm{y}(\mathrm{x} 1, \mathrm{x} 2,)=\frac{\mathrm{a}_{1} \Sigma \mathrm{X}_{1}+\mathrm{a}_{2} \Sigma \mathrm{X}_{2}}{\Sigma \mathrm{Y}^{2}}
$$

$$
\begin{array}{cl}
R^{2}\left(X^{1}, X^{2}\right): \text { Koefisien korelasi } \mathrm{Y} \text { dengan } \mathrm{X}_{1}, \mathrm{X}_{2} \\
a_{1}: \text { Koefisien prediktor } \mathrm{X}_{1} \\
a^{2} & : \text { Koefisien prediktor } \mathrm{X}_{2} \\
\sum X_{1} Y & : \text { Jumlah produk antara } \mathrm{X}_{1} \text { dengan } \mathrm{Y} \\
\sum X_{2} Y & : \text { Jumlah produk antara } \mathrm{X}_{2} \text { dengan } \mathrm{Y} \\
\sum Y^{2} & : \text { Jumlah kuadrat kriterium } \mathrm{Y} \text { (Hadi, 2004) }
\end{array}
$$

\section{Hasil dan Pembahasan}

Gambaran Mahasiswa Manajemen. Universitas muhammadiyah Sorong mempunyai 7 Fakultas dan 13 Program Studi yaitu: FISIP, Hukum, Teknik, Pertanian, Perikanan, Keguruan dan Ilmu Pendidikan dan Ekonomi, Jurusan Manajemen. melaksanakan program Strata Satu (S1) Jumlah mahasiswa yang terdaftar mulai semester 
I sampai dengan semester 8 berjumlah 854 orang, dengan rincian semester I/II sebanyak 150 orang, semester III/IV 159 orang dan semester V/VI sebanyak 98 orang, sedangkan semester VII/VIII sebanyak 97 Orang Per tahun 2017/2018. Rata-rata setiap tingkatan terdiri dari kelas A dan B, kelas A adalah mahasiswa yang belum bekerja dan Kela B Hampir di Setiap kelas ada mahasiswa yang sudah bekerja dan berwirausaha.

\section{Deskripsi Responden}

Penelitian ini mengambil sampel mahasiswa semester IV dan VI yang belum bekerja maupun yang sudah bekerja . Identitas responden. Responden diambil purpose sampling sebanyak 116 orang dari populasi. Deskripsi responden jenis kelamin dan status responden disajikan pada Tabel 1 .

Tabel 1. Deskripsi Responden

\begin{tabular}{cccc}
\hline No. & Keterangan & Jumlah & Percent \\
\hline 1 & Laki-Laki & 26 & $22.40 \%$ \\
2 & Perempuan & 90 & $77.60 \%$ \\
& Jumlah & 116 & $100.00 \%$ \\
\hline
\end{tabular}

\begin{tabular}{clcccr}
\hline \multirow{2}{*}{ No. } & \multicolumn{1}{c}{ Status Responden } & \multicolumn{2}{c}{ Jenis Kelamin } & \multirow{2}{*}{ Jml } & \multirow{2}{*}{$\%$} \\
\hline 1 & Tidak Bekerja \& Tidak Berwirausaha & 11 & 40 & 51 & $44.0 \%$ \\
2 & Bekerja & 12 & 20 & 32 & $28.0 \%$ \\
3 & Berwirausaha & 3 & 26 & 29 & $25.0 \%$ \\
4 & Bekerja dan Berwirausaha & 0 & 4 & 4 & $3.0 \%$ \\
& $\quad$ TOTAL & 26 & 90 & 116 & $100.0 \%$ \\
\hline
\end{tabular}

\section{Hasil Uji Instrumen}

Hasil penelitian sangat ditentukan oleh instrumen atau alat ukur yang digunakan. Bila instrumen yang digunakan tidak atau kurang valid, maka hasil validitas eksternal instrumen diuji dengan cara membandingkan untuk mencari kesamaan antara kriteria yang ada pada instrumen dengan fakta-fakta empiris yang terjadi. Oleh karena itu, instrumen penelitian yang digunakan harus diuji valid dan reliabel atau tidaknya instrumen tersebut.

\section{Uji Validitas}


Uji validitas dengan menggunakan software SPSS diperoleh hasil uji bahwa seluruh item pertanyaan adalah valid karena, uji validitas dilakukan pada setiap butir pertanyaan, dan hasilnya dapat dilihat melalui hasil $r$-hitung yang dibandingkan dengan $\mathrm{r}_{\text {-tabel }}$, dimana $\mathrm{r}$ tabel dapat diperoleh melalui df (degree of freedom) $=\mathrm{n}-2($ signifikan $5 \%, \mathrm{n}=$ jumlah sampel). Jika $\mathrm{r}_{\text {-tabel }}<\mathrm{r}$-hitung maka valid Jika $\mathrm{r}_{\text {-tabel }}>\mathrm{r}$-hitung maka tidak valid.

\section{Uji Reliabilitas}

Hasil Uji realibilitas kuesioner ini di dilakukan secara bersama-sama terhadap seluruh butir pertanyaan. Jika nilai Cronbach's Alpha > 0,60 maka reliable. Pengujian ditunjukkan pada Tabel 3. menunjukkan nilai Cronbach's Alpha 0,840 >0,60. Artinya bahwa kuesioner dalam penelitian ini adalah reliabel.

\section{Tabel. 3 Uji Realiabilitas}

\begin{tabular}{|c|c|c|c|}
\hline \multicolumn{4}{|c|}{ Case Processing Summary } \\
\hline & & $\mathbf{N}$ & $\%$ \\
\hline \multirow{3}{*}{ Cases } & Valid & 116 & 100.0 \\
\hline & Excluded $^{\mathrm{a}}$ & 0 & 0 \\
\hline & Total & 116 & 100.0 \\
\hline
\end{tabular}

a. Listwise deletion based on all variables in the procedure.

\section{Reliability Statistics}

\begin{tabular}{rr}
\hline $\begin{array}{c}\text { Cronbach's } \\
\text { Alpha }\end{array}$ & N of Items \\
\hline .840 & 30 \\
\hline
\end{tabular}

\section{Pengujian Hipotesis}

Cara untuk meramalkan bagaimana pengaruh tersebut, maka harus dicari persamaan regresinya terlebih dahulu, dari tiga instrumen yang dikembangkan untuk menjaring data tentang pengaruh tersebut. Untuk menilai $a, b_{1}, b_{2}$ dapat menggunakan persamaan berikut (untuk regresi satu prediktor) Regresi Linear Sederhana:

$$
\mathrm{Y}^{\prime}=\mathrm{a}+\mathrm{b}_{1} \mathrm{X}_{1}
$$

Keterangan: 


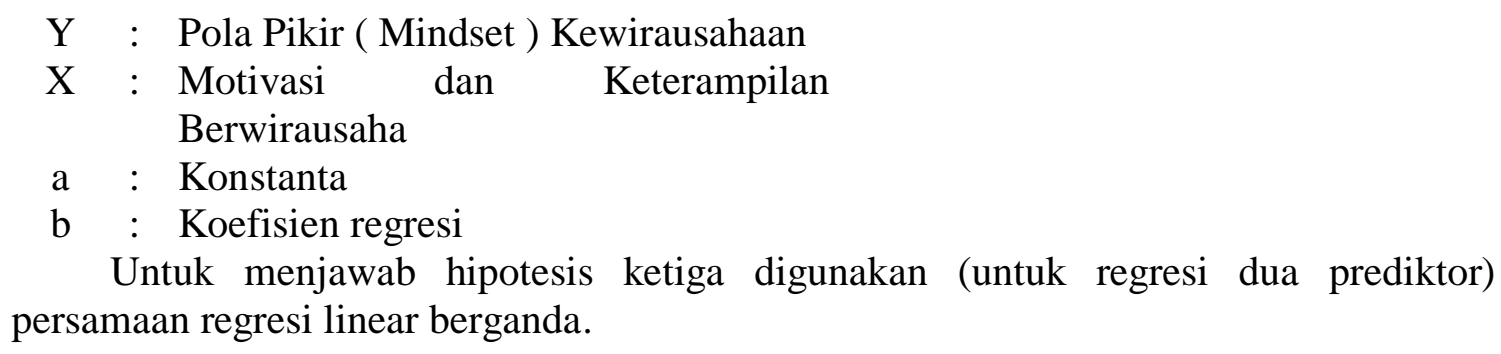

Keterangan:

$$
Y^{\prime}=a+b_{1} X_{1}+b_{2} X_{2}+\ldots . .+b n X n
$$

$$
\begin{array}{cll}
\mathrm{Y}_{1} & : \text { Pola Pikir ( Mindset) Kewirausahaan } \\
\mathrm{X}_{1} & : \text { Motivasi Berwirausaha } \\
\mathrm{X}_{2} & : \text { Keterampilan Berwirausaha } \\
\mathrm{a} & : \text { Konstanta }
\end{array}
$$

\section{Koefisien Korelasi Sederhana dan Berganda}

Koefisien korelasi berganda disajikan pada Tabel 4. Tabel 5 dan Tabel 6 memberi informasi seberapa baik model analisis secara keseluruhan, yaitu bagaimana variabel bebas mampu memprediksikan satu variabel terikat. Rinciannya adalah sebagai berikut. Nilai R dapat dicari dengan menggunakan rumus:

$$
\mathrm{R}^{2}(\mathrm{x} 1 \mathrm{y})=\frac{\mathrm{a}_{1} \Sigma_{\mathrm{x} 1} \mathrm{y}}{\Sigma \mathrm{y}^{2}} \quad \mathrm{R}^{2}(\mathrm{x} 2 \mathrm{y})=\frac{\mathrm{a}_{2} \Sigma_{\mathrm{x} 2} \mathrm{y}}{\Sigma \mathrm{y}^{2}}
$$

Tabel 4. Model Summary $\left(\mathbf{X}_{1}\right)$ Motivasi Berwirausaha

\begin{tabular}{|c|c|c|c|c|c|c|c|c|c|c|}
\hline \multicolumn{11}{|c|}{ Model Summary ${ }^{b}$} \\
\hline \multirow[t]{2}{*}{ Model } & \multirow[t]{2}{*}{$\mathbf{R}$} & \multirow{2}{*}{$\begin{array}{c}\text { R } \\
\text { Square }\end{array}$} & \multirow{2}{*}{$\begin{array}{c}\text { Adjusted R } \\
\text { Square }\end{array}$} & \multirow{2}{*}{$\begin{array}{c}\text { Std. Error } \\
\text { of the } \\
\text { Estimate }\end{array}$} & \multicolumn{5}{|c|}{ Change Statistics } & \multirow{2}{*}{$\begin{array}{l}\text { Durbin- } \\
\text { Watson }\end{array}$} \\
\hline & & & & & $\begin{array}{c}\text { R Square } \\
\text { Change }\end{array}$ & $\begin{array}{c}\mathbf{F} \\
\text { Change }\end{array}$ & df1 & df2 & $\begin{array}{c}\text { Sig. F } \\
\text { Change }\end{array}$ & \\
\hline 1 & $.400^{\mathrm{a}}$ & .160 & .153 & 4.641 & .160 & 21.708 & 1 & 114 & .000 & 1.994 \\
\hline
\end{tabular}
Model Summary ${ }^{\mathrm{b}}$

\begin{tabular}{ccccccccccc}
\hline Model & $\mathbf{R}$ & \multirow{2}{*}{$\begin{array}{c}\text { R } \\
\text { Square }\end{array}$} & $\begin{array}{c}\text { Adjusted R } \\
\text { Square }\end{array}$ & $\begin{array}{c}\text { Std. Error } \\
\text { of the }\end{array}$ & $\begin{array}{c}\text { R Square } \\
\text { Estimate }\end{array}$ & $\begin{array}{c}\text { F } \\
\text { Change }\end{array}$ & $\begin{array}{c}\text { Change Statistics } \\
\text { Change }\end{array}$ & df2 & $\begin{array}{c}\text { Sig. F } \\
\text { Change }\end{array}$ & Durbin- \\
Watson \\
\hline 1 & $.505^{\mathrm{a}}$ & .255 & .248 & 4.371 & .255 & 38.963 & 1 & 114 & .000 & 1.811 \\
\hline
\end{tabular}

a. Predictors: (Constant), Motivasi Berwirausaha

b. Dependent Variable: Pola Pikir(Mindset) Kewirausahaan

Tabel 5. Model Summary $\left(X_{2}\right)$ Keterampilan Berwirausaha

Tabel 6. Model Summary (Y) Pola Pikir(Mindset) Kewirausahaan 
Sentralisasi Volume 8 ( 1 ) : Hal 1-17 | 2019

Pola Pikir (Mindset) Kewirausahan...

DOI: https://doi.org/10.33506/sl.v8i1.385

Helmi Suaidy

\begin{tabular}{|c|c|c|c|c|c|c|c|c|c|c|}
\hline \multicolumn{11}{|c|}{ Model Summary ${ }^{b}$} \\
\hline Model & $\mathbf{R}$ & $\mathbf{R}$ & Adjusted R & Std. Error & & Change & tatisti & & & Durbin- \\
\hline & & Square & Square & $\begin{array}{c}\text { of the } \\
\text { Estimate }\end{array}$ & $\begin{array}{l}\text { R Square } \\
\text { Change }\end{array}$ & $\begin{array}{c}\mathbf{F} \\
\text { Change }\end{array}$ & df1 & df2 & $\begin{array}{c}\text { Sig. F } \\
\text { Change }\end{array}$ & Watson \\
\hline 1 & $.530^{\mathrm{a}}$ & .280 & .268 & 4.314 & .280 & 22.019 & 2 & 113 & .000 & 1.912 \\
\hline
\end{tabular}

Kolom R 0,505( $\left.\mathrm{X}_{1}\right), 0,400\left(\mathrm{X}_{2}\right), 0.530(\mathrm{Y})$. Menunjukkan bahwa variabel-variabel bebas memprediksikan hasil (multiple correlation coefficient). Kisaran nilai $\mathrm{R}$ adalah 0 hingga 1. Semakin nilai $\mathrm{R}$ mendekati angka 1, maka semakin kuat variabel-variabel bebas memprediksikan variabel terikat. Ketepatan nilai $\mathrm{R}$ ini akan lebih disempurnakan oleh kolom Adjusted R Square yang merupakan koreksi atas nilai R. Kolom Adjusted R Square sebesar 0,396 menunjukkan bahwa nilai Adjusted R Square kecil masih dalam kisaran standar. Kisaran nilai Adjusted R Square adalah 0 hingga 1. Nilai Koefisien Determinasi $\left(\mathrm{R}^{2}\right)$ didapat sebesar 0,248 $\left(\mathrm{X}_{1}\right), 0,153\left(\mathrm{X}_{2}\right), 0.268(\mathrm{Y})$.

\section{F Hitung}

F hitung dapat dihitung dengan menggunakan rumus:

$$
\mathrm{F}_{\mathrm{h}}=\frac{\mathrm{R}^{2} / \mathrm{k}}{\left(1-\mathrm{R}^{2}\right) /(\mathrm{n}-\mathrm{k}-1)}
$$

Berdasarkan hasil output analisis regresi, dapat diketahui nilai F seperti pada Tabel 7

Tabel 7. Uji F Anova

\begin{tabular}{llrrrrr}
\multicolumn{1}{c}{ MNOVA $^{\mathbf{a}}$} & & & \\
\hline & Model & \multicolumn{1}{c}{ Sum of } & df & Mean Square & F & Sig. \\
& Squares & & & & & \\
\hline \multirow{2}{*}{1} & Regression & 819.701 & 2 & 409.850 & 22.019 & $.000^{\mathrm{b}}$ \\
& Residual & 2103.334 & 113 & 18.614 & & \\
& Total & 2923.034 & 115 & & & \\
\hline
\end{tabular}

a. Dependent Variable: Pola Pikir(Mindset) Kewirausahaan

b. Predictors: (Constant), Motivasi Berwirausaha, Keterampilan Berwirausaha

\section{Uji Hipotesis}

Berdasarkan uji hipotesis yang dilakukan pertama adalah Uji parsial atau disebut juga uji t bertujuan untuk mengetahui 1) Apakah Motivasi Berwirausaha $\left(\mathrm{X}_{1}\right)$ berpengaruh 
signifikan terhadap Pola Pikir ( Mindset ) Kewirausahaan (Y). 2) Apakah Keterampilan Berwirausaha $\left(\mathrm{X}_{2}\right)$ berpengaruh signifikan terhadap Pola Pikir ( Mindset) Kewirausahaan $(\mathrm{Y})$. Uji kedua adalah pengaruh Motivasi $\left(\mathrm{X}_{1}\right)$ dan Keterampilan Berwirausaha $\left(\mathrm{X}_{2}\right)$ terhadap Pola Pikir ( Mindset) Kewirausahaan secara bersama-sama (simultan) atau disebut dengan uji F. Uji statistik menggunakan software SPSS for Windows seri 20.0. Hasil Output Uji Parsial dan Simultan pada Tabel 8 Sebagai berikut.

\section{Tabel 8. Hasil Output Uji Parsial}

\begin{tabular}{|c|c|c|c|c|c|c|c|}
\hline \multicolumn{8}{|c|}{ Coefficients $^{\mathrm{a}}$} \\
\hline & \multirow[t]{2}{*}{ Model } & \multicolumn{2}{|c|}{$\begin{array}{l}\text { Unstandardized } \\
\text { Coefficients }\end{array}$} & \multirow{2}{*}{$\begin{array}{c}\text { Standardized } \\
\text { Coefficients } \\
\text { Beta }\end{array}$} & & \multirow[t]{2}{*}{$\mathbf{t}$} & \multirow[t]{2}{*}{ Sig. } \\
\hline & & B & Std. Error & & & & \\
\hline \multirow{3}{*}{1} & (Constant) & 26.207 & 4.808 & & & 5.451 & .000 \\
\hline & Variabel $X_{2}$ & .287 & .143 & & .188 & 2.009 & .047 \\
\hline & Variabel $X_{1}$ & .660 & .152 & & .407 & 4.349 & .000 \\
\hline
\end{tabular}

Intrepretasi hasil output SPSS di atas kita dapat melihat dimana nilai t hitung variabel $\mathrm{X}_{1}$ lebih besar dari pada nilai t tabel $(2,009>1.98118)$ dengan tingkat signifikan dibawah 0,05 yaitu 0,047 dan $t$ hitung variabel $\mathrm{X}_{2}$ lebih besar dari pada nilai t tabel $(4,349>1.98118)$ dengan tingkat signifikan dibawah 0,05 yaitu 0,000. Berdasarkan cara pengambilan keputusan uji parsial dalam analisis regresi dapat disimpulkan sebagai berikut, (1) Variabel Motivasi Berwirausaha secara parsial berpengaruh signifikan terhadap Pola Pikir ( Mindset) Kewirausahaan. (2) Variabel Keterampilan secara parsial berpengaruh signifikan terhadap Pola Pikir ( Mindset) Kewirausahaan.

\section{Tabel 9. Hasil Output Uji Simultan}

\begin{tabular}{lrrrrr}
\multicolumn{8}{c}{ ANOVA $^{\text {a }}$} \\
\hline Model & Sum of Squares & \multicolumn{1}{c}{ df } & Mean Square & \multicolumn{1}{c}{ F } & \multicolumn{1}{c}{ Sig. } \\
\hline \multicolumn{1}{c}{ Regression } & 819.701 & 2 & 409.850 & 22.019 & $.000^{b}$ \\
$1 \quad$ Residual & 2103.334 & 113 & 18.614 & & \\
$\quad$ Total & 2923.034 & 115 & & & \\
\hline a. Dependent Variable: Variabel Y & & & & & \\
b. Predictors: (Constant), Variabel $X_{1}$, Variabel $X_{2}$ & & & &
\end{tabular}

Interpretasi hasil output SPSS di atas kita dapat melihat dimana nilai F hitung lebih besar dari pada nilai F tabel (22.019 > 3,08) dengan tingkat signifikan di bawah 0,05 yaitu 0,000. 
Sentralisasi Volume 8 ( 1 ) : Hal 1-17 | 2019

Pola Pikir (Mindset) Kewirausahan...

DOI: https://doi.org/10.33506/sl.v8i1.385

Helmi Suaidy

Berdasarkan cara pengambilan keputusan uji simultan dalam analisis regresi dapat disimpulkan bahwa variabel Motivasi $\left(\mathrm{X}_{1}\right)$ dan Keterampilan Berwirausaha $\left(\mathrm{X}_{2}\right)$ berpengaruh signifikan terhadap Pola Pikir (Mindset) Kewirausahaan Mahasiswa.

\section{Pembahasan}

Penelitian ini dilakukan untuk mengetahui apakah Motivasi dan Keterampilan Berwirausaha berpengaruh signifikan terhadap Pola Pikir ( Mindset) Kewirausahaan Mahasiswa. Responden yang digunakan sebagai sumber data penelitian adalah 116 responden. Pengujian instrumen menunjukkan bahwa instrumen tersebut dapat digunakan dalam penelitian ini. Hasil uji validitas dan uji realibilitas seluruh item pertanyaan adalah valid karena masing-masing item nilai corrected Item-Total Correlation memiliki nilai lebih besar dari standar minimum $(0,3)$ dan nilai Cronbach's Alpha > 0,840. Artinya bahwa semua kuesioner dalam penelitian ini adalah reliabel. Nilai koefisien korelasi berganda menunjukkan angka R 0,280 yang menyatakan bahwa nilai tersebut kisaran nilai $\mathrm{R}$ adalah 0 hingga 1 termasuk katagori rendah, hal tersebut bisa disebabkan oleh sampel yang dituju masih memerlukan pembinaan tentang ilmu kewirausahaan. Nilai Adjusted R Square 0.268 masih dalam kisaran standar namun buruk ketepatannya pada kisaran nilai dibawah angka $<0,10$.

Hasil output analisis regresi dapat diketahui nilai $\mathrm{F}$ sebesar 22,019, tingkat signifikansi menggunakan $\alpha=5 \%$ (signifikansi 5\% atau 0,05). Hasil uji hipotesis menghasilkan bahwa $\mathrm{F}$ hitung $\leq \mathrm{F}$ tabel $=$ Ho diterima, artinya variabel motivasi dan keterampilan berwirausaha tidak berpengaruh signifikan terhadap pola pikir (mindset) kewirausahaan. Hal ini disebabkan karena responden belum memiliki pengalaman dalam berwirausaha. Selanjutnya, penelitian ini terus dikembangkan dan menerapkan motivasi dan Keterampilan berwirausaha dengan menambah pelatihan dan jaringan kerjasama Program Kretifitas Mahasiswa dan UMKM tersebut diharapkan sampel yang diambil pada berikutnya akan menolak Ho dan menerima Ha. Pola berfikir dapat dikatakan berhasil apabila mahasiswa sebagai sasaran diberikan keterampilan / pelatihan yang lebih 
mendalam dan dipraktekkan dalam kondisi real. Penelitian ini akan terus dikembangkan sampai adanya keberhasilan pola berfikir mahasiswa dalam berwirausaha.

\section{Simpulan}

Mahasiswa yang mempunyai pola pikir (Mindset) kewirausahaan dan melatih kepercayaan diri mahasiswa diharapkan akan mengubah pendapat bahwa menjadi wirausaha akan dapat menjanjikan kehidupan yang lebih baik mendorong minat mahasiswa berwirausaha. Untuk menjadi wirausaha tergantung dari pengalaman. Sisi lainnya karena sebagian besar mahasiswa kurang menyukai tantangan dan kurang berani mengambil risiko.

Hasil pengujian hipotesis menunjukkan bahwa uji hipotesis menghasilkan bahwa $\mathrm{F}$ hitung $\leq \mathrm{F}$ tabel $=$ Ho diterima, artinya variabel, motivasi dan Keterampilan tidak berpengaruh signifikan terhadap pola pikir (Mindset) Kewirausahaan mahasiswa. Hal ini disebabkan karena sampel mahasiswa masih ada keragu-raguan dalam berpikir tentang berwirausaha dan masih banyak belum memahami tentang kewirausahaan. Penelitian ini akan terus dikembangkan sampai ada pernyataan bahwa, motivasi dan keterampilan mahasiswa dalam berwirausaha dapat menjadi pola berfikir yang tepat bagi lulusan di Fakultas ekonomi universitas muhammadiyah sorong.

Bagi penelitian selanjutnya disarankan untuk menguji kembali variabel motivasi dan ketermampilan berwirausaha mahasiswa. Penelitian ini lebih bermanfaat bila institusi Universitas Muhammadiyah Sorong dapat menerapkan pada semua jurusan. Hasil penelitian ini menyatakan bahwa sebagian besar mahasiswa belum mempunyai pola pikir ( Mindset) Kewirausahaan. Dengan Melatih kepercayaan diri mahasiswa diharapkan akan mengubah Pola Pikir (Mindset) bahwa menjadi wirausaha akan dapat menjanjikan kehidupan yang lebih baik 


\section{Ucapan Terima Kasih}

Ucapan terima kasih kepada pihak Direktorat Riset dan Pengabdian Kepada Masyarakat,Direktorat Jenderal Penguatan Riset dan Pengembangan Kementerian Riset, Teknologi, dan Pendidikan Tinggi. Yang telah membiayai penelitian ini dan juga Universitas Muhammadiyah Sorong, yang telah memberikan bimbingan dan panduan kepada LPPM Universitas Muhammadiyah Sorong dan memberi kesempatan bagi peneliti untuk mengikuti hibah Penelitian Dosen Pemula (PDP)

\section{Daftar Pustaka}

Alma, Buchari. 2000. Kewirausahaan. Bandung: ALFABETA

Suharsimi.2006. Prosedur Penelitian Suatu Pendekatan Praktik. Jakarta: Rineka Cipta. 2010. Prosedur Penelitian Suatu Pendekatan Praktek. Jakarta: RinekaCipta

Endang Mulyani.2011."Model Pendidikan Kewirausahaan Di Pendidikan Dasar Dan Menengah".vol4:4.Universitas Negeri Yogyakarta.

Ghozali, I.2006."Aplikasi Analisis Multivariate dengan Program SPSS". Semarang :Badan Penerbit Universitas Diponegoro.

Ghozali, Imam. (2013). Aplikasi Analisis Multivariate Dengan Program IBM SPSS21(edisi ketujuh). Semarang: Badan Penerbit Universitas Diponogero.

Kasali, Rhenald, et. all. 2010. Modul Kewirausahaan untuk Program Strata 1. Jakarta Selatan: PT Mizan Publika.

Slameto. 2010. Belajar Dan Faktor-Faktor Yang Mempengaruhinya. Jakarta: Rineka Cipta

Soemanto, Wasty. 1999. Pendidikan Wiraswasta. Jakarta: Bumi Aksara

Sugiyono. 2010. Metode Penelitian Pendidikan (pendekatan Kuanatitatif, Kualitatif,dan R\&D).Bandung: Alfabeta

Sumarsono, Sony.2010.Kewirausahaan.Yogyakarta:Graha Ilmu.

Suryana. 2013. Kewirausahaan:kiat dan proses menuju sukses. Jakarta: Salemba EmpatUndang-Undang Republik Indonesia. 2003. Sistem Pendidikan Nasional (Sisdiknas): Jakarta. Yusuf, A. Muri. 2013. Metode Penelitian Kuantitatif, Kualitatif dan Penelitian Gabungan. Padang: UNP Press.

Roziqin, Miftahur. 2011. Entrepreneurship Adalah Sebuah Mindset. Diakses pada tanggal 2 Maret 2013 darihttp :// miftahur. com/entrepreneurship-adalah-sebuahmindset.

Wahyudi, Sandi. Tanpa tahun. Entrepreneurial Mindset. Diakses pada tanggal 2 Maret 2013 darihttp://ml.scribd.com/doc/35176101/Entrepreneurial-Mindset.

Zimmerer, Thomas W. dan Norman M. Scarborough.2008.Kewirausahaan dan Manajemen Usaha Kecil.Jakarta:Salemba Empat 
Sentralisasi Volume 8 ( 1 ) : Hal 1-17 | 2019

Pola Pikir (Mindset) Kewirausahan... DOI: https://doi.org/10.33506/sl.v8i1.385

Helmi Suaidy 